July 2010

\title{
Antispasmodic, Bronchodilator and Blood Pressure Lowering Properties of Hypericum oblongifolium - Possible Mechanism of Action
}

Arif-ullah Khan

Aga Khan University

Munasib Khan

Fazal Subhan

Anwar Gilani

Aga Khan University

Follow this and additional works at: http://ecommons.aku.edu/pakistan_fhs_mc_bbs

Part of the Circulatory and Respiratory Physiology Commons, and the Natural Products Chemistry and Pharmacognosy Commons

\section{Recommended Citation}

Khan, A., Khan, M., Subhan, F., Gilani, A. (2010). Antispasmodic, Bronchodilator and Blood Pressure Lowering Properties of Hypericum oblongifolium - Possible Mechanism of Action. Phytotherapy Research, 24(7), 1027-1032.

Available at: http://ecommons.aku.edu/pakistan_fhs_mc_bbs/35 


\title{
Antispasmodic, Bronchodilator and Blood Pressure Lowering Properties of Hypericum oblongifolium - Possible Mechanism of Action
}

\author{
Arif-ullah Khan ${ }^{1,2}$, Munasib Khan ${ }^{3}$, Fazal Subhan ${ }^{4}$ and Anwarul Hassan Gilani ${ }^{1}$ * \\ ${ }^{1}$ Natural Product Research Division, Department of Biological and Biomedical Sciences, The Aga Khan University Medical \\ College, Karachi-74800, Pakistan \\ ${ }^{2}$ Institute of Pharmaceutical Sciences, Kohat University of Science and Technology, Kohat-26000, Pakistan \\ ${ }^{3}$ Department of Pharmacy, University of Malakand, Chakdara, Pakistan \\ ${ }^{4}$ Department of Pharmacy, University of Peshawar, Peshawar, Pakistan
}

\begin{abstract}
The crude extract of Hypericum oblongifolium (Ho.Cr), which tested positive for flavonoids, saponins and tannins caused concentration-dependent $(0.1-1.0 \mathrm{mg} / \mathrm{mL})$ relaxation of spontaneous and high $\mathrm{K}^{+}(80 \mathrm{mM})$ induced contractions in isolated rabbit jejunum preparations, suggesting a $\mathbf{C a}^{++}$antagonistic effect, which was confirmed when pretreatment of the tissue with $\mathrm{Ho}$.Cr produced a rightward shift in the $\mathrm{Ca}^{++}$concentrationresponse curves, like that caused by verapamil. Ho.Cr relaxed carbachol $(1 \mu \mathrm{M})$ and high $\mathrm{K}^{+}$-induced contractions in guinea pig tracheal preparations. It caused a dose-dependent $(3-100 \mathrm{mg} / \mathrm{kg})$ fall in arterial blood pressure of rats under anesthesia. In isolated guinea pig atria, Ho.Cr caused inhibition of both atrial force and rate of spontaneous contractions. When tested in rabbit aortic rings, Ho.Cr exhibited a vasodilator effect against phenylephrine $(1 \mu \mathrm{M})$ and high $\mathrm{K}^{+}$-induced contractions. These results indicate that Ho.Cr possesses gastrointestinal, respiratory and cardiovascular inhibitory effects, mediated via a $\mathrm{Ca}^{++}$antagonist mechanism. Copyright (C) 2009 John Wiley \& Sons, Ltd.
\end{abstract}

Keywords: Hypericum oblongifolium; antispasmodic; bronchodilator; antihypertensive; $\mathrm{Ca}^{++}$antagonist.

\section{INTRODUCTION}

The genus Hypericum consists of about 400 species with widespread medicinal applications in a variety of health disorders. Hypericum oblongifolium WALL is an erect evergreen shrub, usually 6-12 m high, belonging to the family Hypericaceae. It is common on Khasia Hill at 5000-6000 m altitude, in China and the Himalayas (Chopra et al., 1998). In Pakistan, it occurs in Hazara, Murree Hills and Kashmir (Nasir and Ali, 1973). It is used in the traditional medical system for the treatment of hepatitis, bacterial diseases, nasal hemorrhage, also considered useful as a remedy for dog bites and bee stings (Chang, 1994). The plant is known to contain hyperinols A and B. Hypericum oblongifolium showed strong cytotoxicity in a brine shrimp lethality test. Further screening revealed its inhibitory activity against chymotrypsin (Ferheen et al., 2006). This plant has not been evaluated pharmacologically in detail so far. In this investigation we, for the first time, report the antispasmodic, bronchodilator, hypotensive and cardiovascular inhibitory activities of Hypericum oblongifolium, mediated through $\mathrm{Ca}^{++}$channel inhibition.

* Correspondence to: Anwarul Hassan Gilani, Professor of Pharmacology, Department of Biological and Biomedical Sciences, The Aga Khan University Medical College, Karachi-74800, Pakistan.

E-mail: anwar.gilani@aku.edu

\section{MATERIALS AND METHODS}

Plant material and preparation of extract. The aerial parts (stem + leaves) of Hypericum oblongifolium were collected from the northern areas of Pakistan (Gillyat). The plant was identified with help of the taxonomist Dr M. Ibrar, at the Department of Pharmacy, University of Peshawar, and the sample specimen (PUP 7513) has been submitted to the herbarium of the Department of Botany of the same university. The plant materials were cleaned, shade dried and coarsely ground. The powdered material (1193 g) was soaked in $70 \%$ aqueousethanol for 3 days with occasional shaking. It was filtered through a muslin cloth and then through a filter paper (Williamson et al., 1998). This procedure was repeated twice and the combined filtrate was evaporated on a rotary evaporator, under reduced pressure, to a thick semi-solid mass of dark brown color, i.e., the crude extract of Hypericum oblongifolium (Ho.Cr), yielding approximately $18.4 \%$. Ho.Cr was completely solubilized in saline/distilled water.

Chemicals. Acetylcholine chloride (ACh), atropine sulphate, carbachol (CCh), isoprenaline hydrochloride, norepinephrine hydrochloride (NE), phenylephrine hydrochloride (PE) and verapamil hydrochloride were purchased from Sigma Chemicals Co. (St Louis, MO, USA). Pentothal sodium (thiopental sodium) was obtained from Abbott Laboratories (Karachi, Pakistan). The following chemicals were used to make the physiological salt solutions: potassium chloride (Sigma 
Chemical Company, St. Louis, MO, USA), calcium chloride, glucose, magnesium chloride, magnesium sulphate, potassium dihydrogen phosphate, sodium bicarbonate, sodium chloride, sodium dihydrogen phosphate, (E. Merck, Darmstadt, Germany) and ethylene diaminetetraacetic acid (EDTA) from BDH Laboratory Supplies (Poole, England). Chemicals used in the phytochemical analysis include: acetic anhydride, aluminum chloride, ammonium hydroxide, Dragendorff's reagent, ferric chloride (Sigma Chemical Co., St Louis, MO, USA), benzene, chloroform, hydrochloric acid and petroleum ether (BDH Laboratory Supplies, Poole, England). All chemicals used were of the highest analytical grade available.

Animals. Adult rabbits (1-1.2 kg) and guinea pigs (500-550 g) of local breed, Sprague-Dawley rats (180$200 \mathrm{~g})$ and Balb-C mice (20-25 g) of either sex were used for this study. Animals were housed at the Animal House of the Aga Khan University, maintained at $23-25^{\circ} \mathrm{C}$ and were given a standard diet and tap water. Rabbits starved for $24 \mathrm{~h}$ were sacrificed by a blow on back of the head and guinea pigs by cervical dislocation. Experiments performed complied with rulings of the Institute of Laboratory Animal Resources, Commission on Life Sciences, National Research Council (1996) and approved by the Ethical Committee of the Aga Khan University.

Phytochemical analysis. Preliminary phytochemical analysis for the detection of various classes, such as alkaloids, saponins, coumarins, sterols, terpenes, flavonoids, tannins and anthraquinones was carried out according to standard procedures (Edeoga et al., 2005; Khan and Gilani, 2008).

Rabbit jejunum. The jejunum was dissected out by opening the rabbit abdomen, immersed in Tyrode's solution and cleaned of mesenteries (Gilani et al., 2007). Each segment of about $2 \mathrm{~cm}$ length was suspended in a $10 \mathrm{~mL}$ tissue bath containing Tyrode's solution, maintained at $37^{\circ} \mathrm{C}$ and aerated with a mixture of $95 \%$ oxygen and $5 \%$ carbon dioxide (carbogen). The composition of the Tyrode's solution in $\mathrm{mM}$ was: $\mathrm{KCl} 2.68, \mathrm{NaCl} 136.9, \mathrm{MgCl}_{2} 1.05, \mathrm{NaHCO}_{3}$ $11.90, \mathrm{NaH}_{2} \mathrm{PO}_{4} 0.42, \mathrm{CaCl}_{2} 1.8$ and glucose 5.55. Intestinal responses were recorded isotonically using Bioscience transducers and a Harvard oscillograph. Each tissue was allowed to equilibrate for at least $30 \mathrm{~min}$ before the addition of any drug and then stabilized with a submaximal concentration of ACh $(0.3 \mu \mathrm{M})$ with a 3-min interval until constant responses were recorded. Under these experimental conditions, the rabbit jejunum exhibits spontaneous rhythmic contractions, allowing the testing of relaxant (spasmolytic) activity, directly without the use of an agonist. For the determination of $\mathrm{Ca}^{++}$channel blocking (CCB) activity, high $\mathrm{K}^{+}(80 \mathrm{mM})$ was used to depolarize the preparations as described by Farre et al. (1991). $\mathrm{K}^{+}$was added to the tissue bath, which produced a sustained contraction. Test materials were then added in a cumulative fashion to obtain concentration-dependent inhibitory responses (van Rossum, 1963). To confirm the $\mathrm{Ca}^{++}$ antagonist effect of the test substance, the tissue was allowed to stabilize in normal Tyrode's solution, which was then replaced with $\mathrm{Ca}^{++}$-free Tyrode's solution con- taining EDTA $(0.1 \mathrm{mM})$ for $30 \mathrm{~min}$ in order to remove $\mathrm{Ca}^{++}$from the tissues. This solution was further replaced with $\mathrm{K}^{+}$-rich and $\mathrm{Ca}^{++}$-free Tyrode's solution of the following composition (mM): $\mathrm{KCl} 50, \mathrm{NaCl} 91.04, \mathrm{MgCl}_{2}$ 1.05, $\mathrm{NaHCO}_{3} 11.90, \mathrm{NaH}_{2} \mathrm{PO}_{4} 0.42$, glucose 5.55 and EDTA 0.1. Following an incubation period of $30 \mathrm{~min}$, control concentration-response curves (CRCs) of $\mathrm{Ca}^{++}$ were obtained. When the control $\mathrm{Ca}^{++} \mathrm{CRCs}$ were found super-imposable (usually after two cycles), the tissue was pretreated with the plant extract for $60 \mathrm{~min}$ to test the possible CCB effect. The CRCs of $\mathrm{Ca}^{++}$were constructed in the presence of different concentrations of the test material.

Guinea pig trachea. The trachea was dissected out from the guinea pigs and kept in Kreb's solution. The tracheal tube was cut into rings, 2-3 mm wide, each containing about 2 cartilages. Each ring was opened by a longitudinal cut on the ventral side opposite to the smooth muscle layer, forming a tracheal strip with a central part of smooth muscle in between the cartilaginous portions on the edges (Khan and Gilani, 2006). The preparation was then mounted in a $20 \mathrm{~mL}$ tissue bath containing Krebs solution, at $37^{\circ} \mathrm{C}$ and aerated with carbogen. The composition of Krebs solution was (mM): $\mathrm{NaCl} 118.2, \mathrm{NaHCO}_{3} 25.0, \mathrm{CaCl}_{2} 2.5, \mathrm{KCl} 4.7$, $\mathrm{KH}_{2} \mathrm{PO}_{4} 1.3, \mathrm{MgSO}_{4} 1.2$ and glucose 11.7 (pH 7.4). A tension of $1 \mathrm{~g}$ was applied to each of the tracheal strips and was kept constant throughout the experiment. The tissue was equilibrated for $1 \mathrm{~h}$ before the addition of any drug. The CCh $(1 \mu \mathrm{M})$ and $\mathrm{K}^{+}(80 \mathrm{mM})$ were used to stabilize the respective preparations until constant responses of each agonist were achieved (usually 3-4 contractions). The sustained contractions were induced with respective agonists and the relaxant effect of the test substance was assessed by addition in a cumulative fashion. Isometric responses were measured via a forcedisplacement transducer (FT-03) using a Grass model 7 Polygraph (Grass Instrument Company, Quincy, MA, USA).

Guinea pig atria. Right atria from the guinea pigs were dissected out, cleaned of fatty tissue and mounted individually in $20 \mathrm{~mL}$ tissue baths containing Krebs solution, at $32^{\circ} \mathrm{C}$ and aerated with carbogen (Ghayur and Gilani, 2005). The tissues were allowed to beat spontaneously (due to the presence of pacemaker cells) under the resting tension of $1 \mathrm{~g}$. This preparation allows studying the effects on both force and rate of atrial contractions. The effect on heart rate was measured by increasing speed of the chart recorder. An equilibrium period of $30 \mathrm{~min}$ was allowed before the application of any drug. Control responses of acetylcholine $(1 \mu \mathrm{M})$ and isoprenaline $(1 \mu \mathrm{M})$ were obtained at least in duplicate. Tension changes in the tissue were recorded via a Grass force-displacement transducer (model FT-03) using a Grass Model 7 Polygraph.

Rabbit aorta. To study the effect on vascular resistance, thoracic aorta ring preparations from rabbit were used. Aortic rings $2-3 \mathrm{~mm}$ wide were individually mounted in $20 \mathrm{~mL}$ tissue baths containing Krebs solution, at $37^{\circ} \mathrm{C}$ and aerated with carbogen. A resting tension of $2 \mathrm{~g}$ was applied to each tissue and an equilibrium period of $1 \mathrm{~h}$ was allowed before studying the effect of test materials. 
PE $(1 \mu \mathrm{M})$ and $\mathrm{K}^{+}(80 \mathrm{mM})$ were used to induce sustained contractions and the vasodilator effect of the extract was assessed by addition in a cumulative fashion (Khan and Gilani, 2008). The changes in isometric tension of the rings were measured via a forcedisplacement transducer (FT-03) using a Grass Model 7 Polygraph.

Measurement of blood pressure in anaesthetized rat. These experiments were performed according to the method described previously (Ghayur and Gilani, 2005). Briefly, rats were anaesthetized with thiopental sodium (Pentothal ${ }^{\circledR}, 70-90 \mathrm{mg} / \mathrm{kg}$, i.p.) and the arterial blood pressure (BP) was recorded through carotid artery cannulation via a pressure transducer (P23 XL) coupled with a Grass Model 7 Polygraph. Drugs were injected through a cannula inserted into the jugular vein. After a 20-min period of equilibrium, the rats were injected intravenously with $0.1 \mathrm{~mL}$ saline $(\mathrm{NaCl} 0.9 \%)$ or with the same volume of test substance. Arterial BP was allowed to return to the resting level between injections. Control responses of standards as ACh $(1 \mu \mathrm{g} / \mathrm{kg})$ and $\mathrm{NE}(1 \mu \mathrm{g} / \mathrm{kg})$ were obtained before testing the extract. Changes in BP were recognized as the difference between the steady state values before and the lowest readings after injection. Mean arterial pressure (MAP) was calculated as the diastolic BP plus one-third pulse width.

Acute toxicity test. Animals were divided into groups of 5 mice each. The test was performed using increasing doses of the plant extract, given orally, in $10 \mathrm{~mL} / \mathrm{kg}$ volume to different groups serving as test groups. Another group of mice was administered saline $(10 \mathrm{~mL} / \mathrm{kg}$, p.o.) as negative control. The mice were allowed food ad libitum and kept under regular observation for $6 \mathrm{~h}$ while the lethality was recorded after $24 \mathrm{~h}$.

Statistical analysis. Data expressed are mean \pm standard error of the mean (SEM, $\mathrm{n}=$ number of experiments) and the median effective concentrations $\left(\mathrm{EC}_{50}\right.$ values) with $95 \%$ confidence intervals (CI). CRCs were analyzed by non-linear regression using the GraphPad program (GraphPAD, San Diego, CA, USA).

\section{RESULTS}

\section{Phytochemical screening}

Ho.Cr was found to contain flavonoids, saponins and tannins, while testing negative for the rest of the classes.

\section{Effect on jejunum}

Ho.Cr caused a concentration-dependent inhibition of spontaneous and $\mathrm{K}^{+}(80 \mathrm{mM})$-induced contractions of rabbit jejunum preparations with $\mathrm{EC}_{50}$ values of 0.34 $(0.17-0.70,95 \% \mathrm{CI}, \mathrm{n}=4)$ and $0.35 \mathrm{mg} / \mathrm{mL}(0.19-0.70$, $\mathrm{n}=4)$ respectively (Fig. 1). Ho. Cr $(0.3-1.0 \mathrm{mg} / \mathrm{mL}$ ) shifted the $\mathrm{Ca}^{++}$CRCs to the right (Fig. 2A) similar to that caused by verapamil (Fig. 2B).

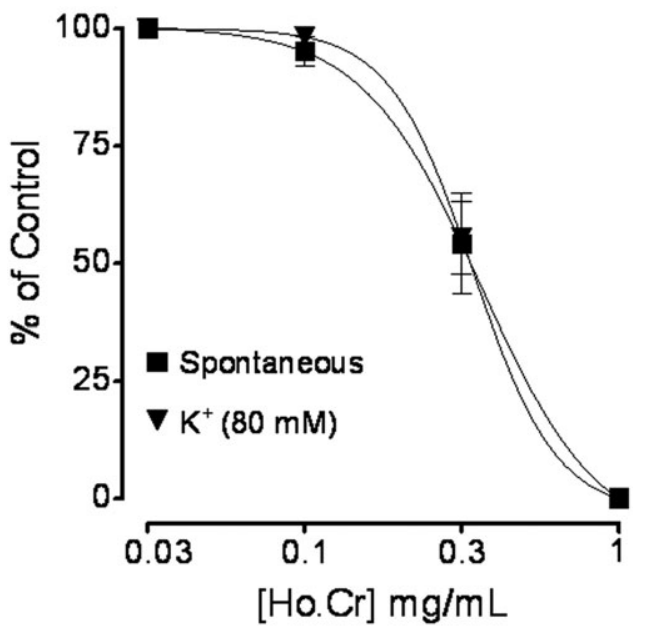

Figure 1. Concentration-dependent inhibitory effects of the crude extract of Hypericum oblongifolium (Ho.Cr) on spontaneous and $\mathrm{K}^{+}$-induced contractions of isolated rabbit jejunum preparations. Symbols represent mean \pm SEM, $n=4$.
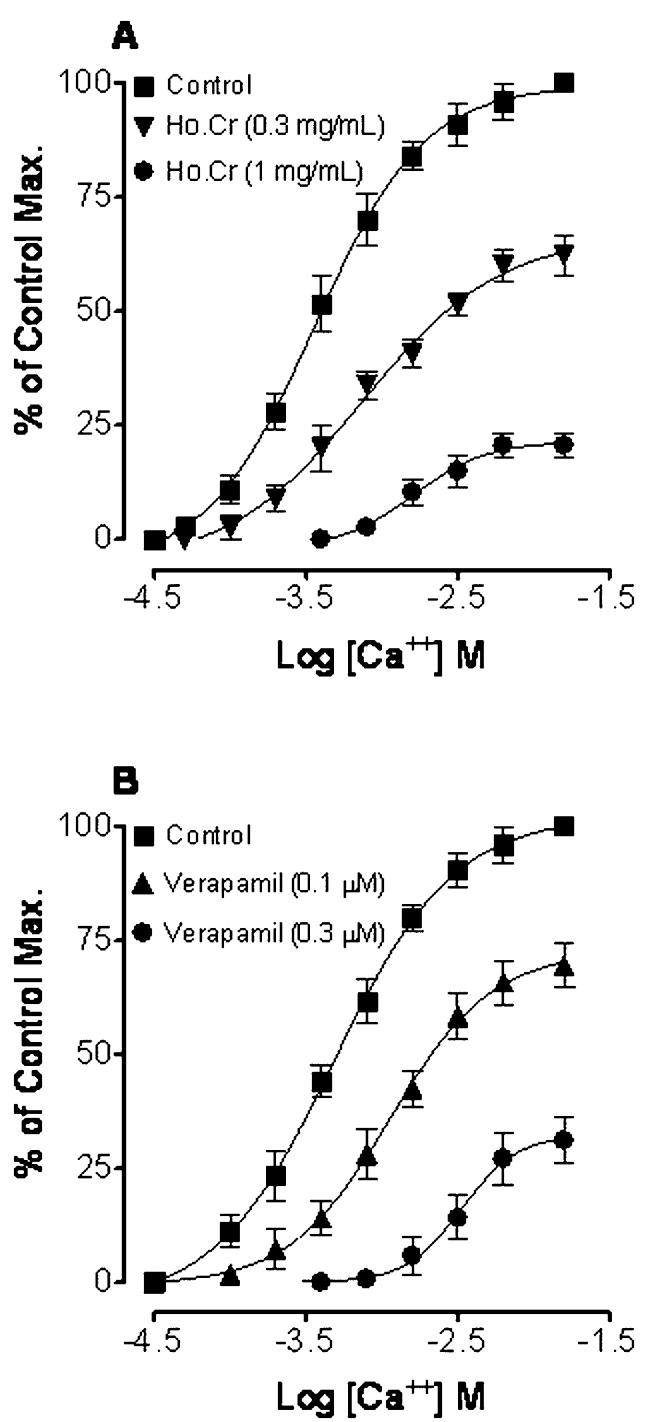

Figure 2. Concentration-response curves of $\mathrm{Ca}^{++}$in the absence and presence of increasing concentrations of $(A)$ crude extract of Hypericum oblongifolium (Ho.Cr) and (B) verapamil in isolated rabbit jejunum preparations. Symbols represent mean \pm SEM, $\mathrm{n}=3-4$. 


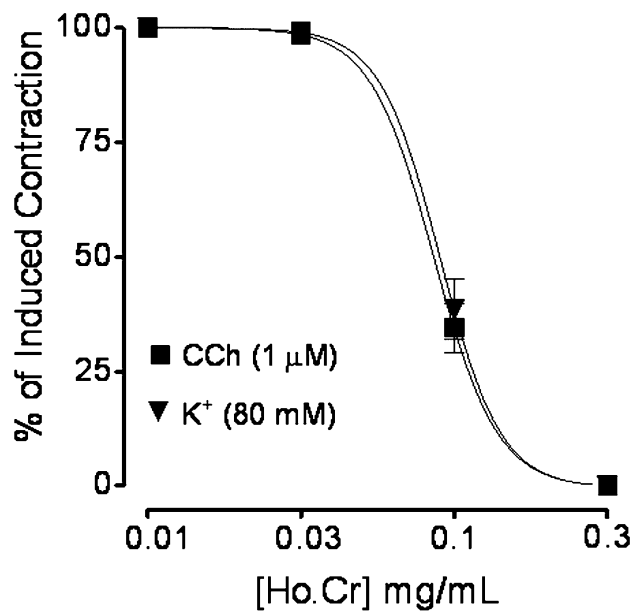

Figure 3. Concentration-dependent inhibitory effects of the crude extract of Hypericum oblongifolium (Ho.Cr) on carbachol (CCh) and $\mathrm{K}^{+}$-induced contractions of isolated guinea pig tracheal preparations. Symbols represent mean \pm SEM, $n=4$.

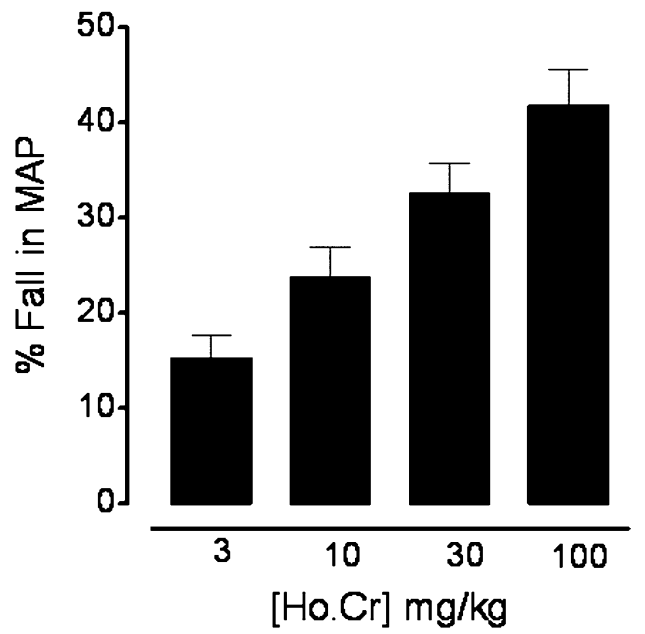

Figure 4. Bar chart representing the dose-dependent effect of the crude extract of Hypericum oblongifolium ( $\mathrm{Ho} . \mathrm{Cr}$ ) on mean arterial pressure (MAP) in anesthetized rats. Values shown represent the mean $\pm S E M, n=4$.

\section{Effect on trachea}

In guinea pig tracheal preparations, precontracted with CCh $(1 \mu \mathrm{M})$ and $\mathrm{K}^{+}(80 \mathrm{mM})$, Ho.Cr caused a concentration-dependent relaxant effect with respective $\mathrm{EC}_{50}$ values of $0.07(0.04-0.13, \mathrm{n}=4)$ and $0.08 \mathrm{mg} /$ $\mathrm{mL}(0.04-0.14, \mathrm{n}=4)$, as shown in Fig. 3 .

\section{Effect on blood pressure}

Intravenous administration of Ho.Cr caused a dosedependent fall in the MAP of anaesthetized rats. The $\%$ fall at the respective doses of 3,10, 30 and $100 \mathrm{mg} / \mathrm{kg}$ was found to be $15.3 \pm 2.5,23.8 \pm 3.2$, $32.5 \pm 3.2$ and $41.7 \pm 3.8($ mean $\pm \mathrm{SEM}, \mathrm{n}=4)$ as shown in Fig. 4.

\section{Effect on atria}

Ho.Cr exerted concentration-dependent inhibitory effects on the atrial force and rate of spontaneous con-

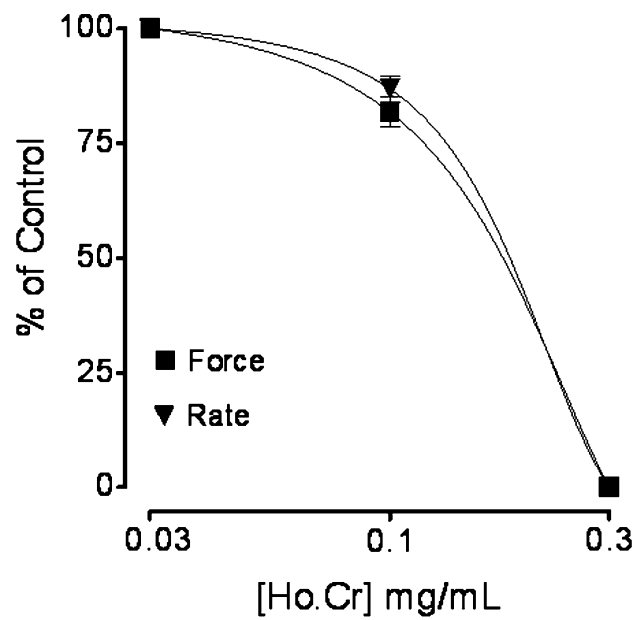

Figure 5. Concentration-dependent inhibitory effects of the crude extract of Hypericum oblongifolium (Ho.Cr) on force and rate of contractions of isolated guinea pig atrial preparations. The symbols represent mean \pm SEM., $n=3-5$.

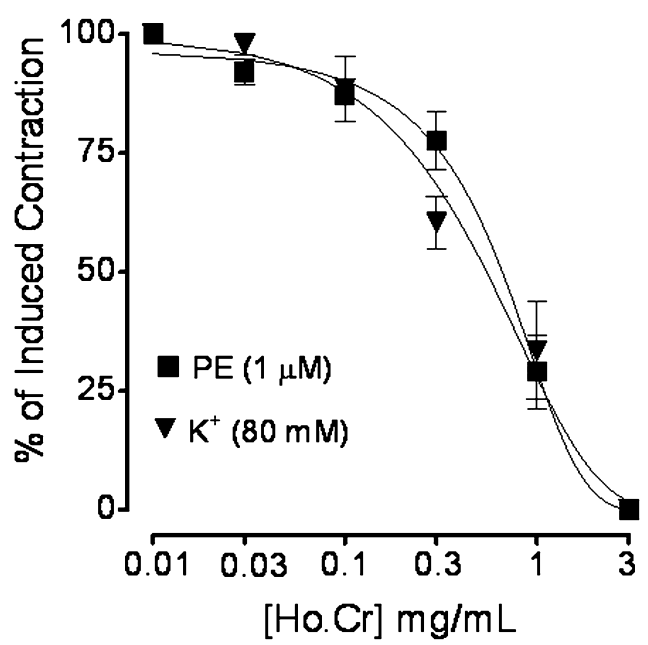

Figure 6. Concentration-dependent inhibitory effects of the crude extract of Hypericum oblongifolium (Ho. $\mathrm{Cr}$ ) on phenylephrine (PE) and $\mathrm{K}^{+}$-induced contractions of isolated rabbit aortic preparations. Symbols represent mean $\pm S E M, n=4$.

tractions with $\mathrm{EC}_{50}$ values of $0.13(0.05-0.31, \mathrm{n}=5)$ and $0.14 \mathrm{mg} / \mathrm{mL}(0.03-0.6, \mathrm{n}=3)$ respectively (Fig. 5). Pretreatment of the tissue with atropine $(1 \mu \mathrm{M})$ did not alter the Ho.Cr effect (data not shown).

\section{Effect on aorta}

When tested on the resting baseline of the rabbit aorta, the plant extract was found devoid of any vasoconstrictor effect up to $10 \mathrm{mg} / \mathrm{mL}$. When tested on the PE $(1 \mu \mathrm{M})$ and $\mathrm{K}^{+}(80 \mathrm{mM})$-induced contractions, Ho.Cr exhibited a concentration-dependent inhibitory effect with $\mathrm{EC}_{50}$ values of $0.74(0.5-1.1, \mathrm{n}=4)$ and $0.55 \mathrm{mg} / \mathrm{mL}$ $(0.35-0.86, \mathrm{n}=4)$ respectively (Fig. 6).

\section{Acute toxicity study}

The two different groups of mice were given $\mathrm{Ho}$. $\mathrm{Cr}$ in the graded doses of 1 and $3 \mathrm{~g} / \mathrm{kg}$ respectively and the 
animals were observed for mortality after $24 \mathrm{~h}$ of drug administration. The extract did not cause any mortality up to the dose of $3 \mathrm{~g} / \mathrm{kg}$.

\section{DISCUSSION}

The hydro-ethanolic extract of Hypericum oblongifolium, when tested in jejunum preparations, inhibited spontaneous contractions, thus showing an antispasmodic effect. The contraction of smooth muscle preparations, including rabbit jejunum, is dependent on an increase in the cytoplasmic free $\left[\mathrm{Ca}^{++}\right]$, which activates the contractile elements (Grasa et al., 2004). The increase in intracellular $\mathrm{Ca}^{++}$is due to either influx via voltage dependant L-type $\mathrm{Ca}^{++}$channels (VDCs) or to a release from intracellular stores in the sarcoplasmic reticulum. Periodic depolarization regulates the spontaneous movements of the intestine and at the height of depolarization the action potential appears as a rapid influx of $\mathrm{Ca}^{++}$via VDCs (Brading, 1981). The inhibitory effect of the plant extract on spontaneous movements of the jejunum may be due to interference either with the $\mathrm{Ca}^{++}$release or with the $\mathrm{Ca}^{++}$influx through VDCs. In our earlier studies, we observed that the spasmolytic effect of medicinal plants is usually mediated through blockade of $\mathrm{Ca}^{++}$channels (Gilani et al., 1994; 2005a; 2005b). To see whether the spasmolytic effect of this plant is also mediated via the same mechanism, the extract was tested on high $\mathrm{K}^{+}(80 \mathrm{mM})$-induced contraction, which was completely relaxed by the plant extract. At high concentration $(>30 \mathrm{mM}), \mathrm{K}^{+}$is known to cause smooth muscle contractions through opening of voltage-dependent calcium channels (VDCs), thus allowing influx of extracellular $\mathrm{Ca}^{++}$causing a contractile effect (Bolton, 1979), and a substance causing inhibition of high $\mathrm{K}^{+}$-induced contraction is considered an inhibitor of $\mathrm{Ca}^{++}$influx (Godfraind et al., 1986). The presence of $\mathrm{Ca}^{++}$antagonist constituent(s) was further strengthened, when the plant extract caused a rightward shift in the $\mathrm{Ca}^{++}$CRCs (constructed in the applied $\mathrm{K}^{+}$-rich and $\mathrm{Ca}^{++}$free medium) and suppressed the maximal response, similar to that caused by verapamil, a standard $\mathrm{Ca}^{++}$ channel blocker (Fleckenstein, 1977). Calcium antagonists constitute an important therapeutic group and the common characteristic of these drugs is their concentration-dependent inhibition of the slow entry of calcium and their capacity for reversal of this effect by $\mathrm{Ca}^{++}$ (Farre et al., 1991). In trachea, the extract caused relaxation of both $\mathrm{CCh}$ and high $\mathrm{K}^{+}$-induced contractions. High $\mathrm{K}^{+}$and $\mathrm{CCh}$, a cholinergic agonist, are known to cause smooth muscle contractions through opening of L- type $\mathrm{Ca}^{++}$channel and stimulation of muscarinic receptors respectively, eventually leading to an increase in the intracellular $\mathrm{Ca}^{++}$level, resulting in a bronchoconstrictor effect. The inhibitory effect of Ho.Cr against the two spasmogens indicates the non-specific bronchodilatory action, possibly mediated through a CCB-like mechanism (Gilani et al., 2007). The plant extract was found to be a more potent spasmolytic in trachea compared to other tissues, which could be due to the heterogeneity of $\mathrm{Ca}^{++}$channels, which are known to be heterogeneous, and different $\mathrm{Ca}^{++}$antagonists have selectivity for different organ systems (Gilani et al., 2005a). In view of the well-established therapeutic use of $\mathrm{Ca}^{++}$channel blockers in cardiovascular disorders, such as hypertension (Epstein, 1992), the plant extract was studied for a possible hypotensive effect. When injected intravenously to normotensive rats, Hypericum oblogifolium caused a dose-dependant fall in arterial BP. As BP is considered the product of cardiac output and peripheral resistance (Ghayur and Gilani, 2005), the extract was studied in heart and vascular preparations for possible cardio-depressant and vasodilator actions. In spontaneously beating guinea pig atria, the extract exhibited negative inotropic and chronotropic effects. The cardiac inhibitory effect was resistant to atropine, as a muscarinic receptor antagonist (Arunlakshana and Schild, 1959), indicating that the cardio-depressant effect of the plant is not mediated through muscarinic receptor stimulation, but possibly via a calcium channel blocker $(\mathrm{CCB})$, as $\mathrm{Ca}^{++}$antagonists are well known for their cardiac inhibitory effect (Khan and Gilani, 2008). When tested in aorta, the extract caused inhibition of both PE and high $\mathrm{K}^{+}-$ induced contractions. PE produces vascular contraction through an increase in cytosolic $\mathrm{Ca}^{++}$, partly due to $\mathrm{Ca}^{++}$ influx via receptor operated channels and partly via $\mathrm{Ca}^{++}$ release from intracellular stores (Graham et al., 1996). The inhibition of both $\mathrm{PE}$ and $\mathrm{K}^{+}$-induced contractions by Ho.Cr suggests a non-specific vasodilatory action, virtue of $\mathrm{Ca}^{++}$antagonism. The observed $\mathrm{Ca}^{++}$antagonist effect of the Hypericum oblongifolium extract might be due to the presence of flavonoids, evident in the phytochemical analysis, as compounds of this class have been reported to possess CCB action (Revuelta et al., 1997; Gilani et al., 2007). These results clearly indicate that Hypericum oblongifolium possesses antispasmodic, bronchodilator, hypotensive, cardiac inhibitory and vasodilator effects, mediated possibly through $\mathrm{Ca}^{++}$antagonism, and this study may provide evidence for the potential therapeutic use of Hypericum oblongifolium in the hyperactive gut, airways and cardiovascular disorders.

\section{Acknowledgement}

This study was supported by the Pakistan Science Foundation (grant no. PSF/Res/S-AKU/Bio-377).

\section{REFERENCES}

Arunlakshana O, Schild HO. 1959. Some quantitative uses of drug antagonism. Br J Pharmacol 14: 48-58.

Bolton TB. 1979. Mechanism of action of transmitter and other substances on smooth muscles. Physiol Rev 59: 606-718.

Brading AF. 1981. How do drugs initiate contractions in smooth muscles. Trends Pharmacol Sci 2: 261-265.

Chang SU. 1994. Dictionary of Chinese crude drugs. Shanghai Scientific Technological Publishers: Shanghai.
Chopra RN, Chopra IC, Verma BS. 1998. Supplement to Glossary of Indian Medicinal Plants. Central Institute of Scientific and Industrial Research: New Delhi; 347.

Edeoga HO, Okwu DE, Mbaebie BO. 2005. Phytochemical constituents of some Nigerian medicinal plants. Afr J Biotechnol 4: 685-688.

Epstein M. 1992. Calcium antagonists in the management of hypertension. In Calcium Antagonists in Clinical Medicine, 
Epstein M (ed.). Hanley and Belfus: Philadelphia; 213230.

Farre AJ, Columbo M, Fort M, Gutierrez B. 1991. Differential effects of various $\mathrm{Ca}^{++}$antagonists. Gen Pharmacol 22: 177-181.

Ferheen S, Ahmed E, Malik A, Afza N, Lodhi MA, Choudhary MI. 2006. Hyperinols $A$ and $B$, chymotrypsin inhibiting triterpenes from Hypericum oblongifolium. Chem Pharm Bull 54: 1088-1090.

Fleckenstein A. 1977. Specific pharmacology of calcium in myocardium, cardiac pacemakers and vascular smooth muscle. Rev Pharmacol Toxicol 17: 149-166.

Ghayur MN, Gilani AH. 2005. Ginger lowers blood pressure through blockade of voltage-dependent calcium channels. J Cardiovasc Pharmacol 45: 74-80.

Gilani AH, Janbaz KH, Lateef A, Zaman M. 1994. Ca+t channel blocking activity of Artemesia scoparia extract. Phytother Res 8: 161-165.

Gilani AH, Shah AJ, Ghayur MN, Majeed K. 2005a. Pharmacological basis for the use of turmeric in gastrointestinal and respiratory disorders. Life Sci 76: 3089-3105.

Gilani AH, Jabeen Q, Ghayur MN, Janbaz KH, Akhtar MS. 2005b. Studies on the antihypertensive, antispasmodic, bronchodilator and hepatoprotective activities of the Carum copticum seed extract. J Ethnopharmacol 98: 127-135.

Gilani AH, Bashir S, Khan A. 2007. Pharmacological basis for the use of Borago officinalis in gastrointestinal, respiratory and cardiovascular disorders. J Ethnopharmacol 114: 393-399.
Godfraind T, Miller R, Wibo M. 1986. Calcium antagonism and calcium entry blockade. Pharmacol Rev 38: 321-416.

Graham RM, Perez DM, Hwa J, Piascik MT. 1996. $\alpha_{1}$-adrenergic receptor subtypes, molecular structure, function and signalling. Cir Res 78: 737-749.

Grasa L, Rebollar E, Arruebo MP, Plaza MA, Murillo MD. 2004. The role of $\mathrm{Ca}^{+2}$ in the contractility of rabbit small intestine in vitro. J Physiol Pharmacol 55: 639-650.

Khan A, Gilani AH. 2006. Selective bronchodilatory effect of Rooibos Tea (Aspalathus linearis) and its flavonoid: chrysoeriol. Eur J Nutr 45: 463-469.

Khan A, Gilani AH. 2008. Cardiovascular inhibitory effects of Hyoscyamus niger. Methods Find Exp Clin Pharmacol 30: 295-300.

Nasir E, Ali SI. 1973. Flora of West Pakistan. Fakhri Printing Press: Karachi; 33.

National Research Council. 1996. Guide for the Care and Use of Laboratory Animals. National Academy Press: Washington; $1-7$.

Revuelta MP, Cantabrana B, Hidalgo A. 1997. Depolarizationdependent effect of flavonoids in rat uterine smooth muscle contraction elicited by $\mathrm{CaCl}_{2}$. Gen Pharmacol 29: 847-857.

van Rossum JM. 1963. Cumulative dose-response curves.11. Techniques for the making of dose-response curves in isolated organs and the evaluation of drug parameters. Arch Int Pharmacodyn Ther 143: 299-330.

Williamson EM, Okpako DT, Evans FJ. 1998. Selection, Preparation and Pharmacological Evaluation of Plant Material. John Wiley \& Sons: Chichester; 15-23. 